\title{
Effect Of Some Plant Extracts and Nicotinamide on Certain Histopathological Aspects In The Red Palm Weevil Larvae, Rhynchophorus Ferrugineus (Oliver) (Coleoptera: Curculionidae)
}

\section{Karam Hussein, Ibrahim Shoukry, Farag Ahmad and Mohamed Gad}

Department of Zoology, Faculty of Science, Zagazig University, Egypt

Correspondence Author: Mohamed Gad, Zagazig University, Department of Zoology, Faculty of Science, Box.44519. Zagazig. Egypt. E-mail: mohamedgad1985@gmail.com

Received date: 23 February 2018, Accepted date: June 2018, Online date: 10 June 2018

Copyright: (C) 2018 Karam Hussein et al. This is an open-access article distributed under the terms of the Creative Commons Attribution License, which permits unrestricted use, distribution, and reproduction in any medium, provided the original author and source are credited.

\begin{abstract}
BACKGROUND The red palm weevil Rhynchophorus ferrugineus (Oliver) is a devastating insect pest of date palm, hatched grubs burrow into the trunk and feed on tissue of the stem, larvae and adult emergence within the same stem allow successive generations. However, little studies had applied on the insecticidal effect against the insect. OBJECTIVE In the present study, Larvae of the red palm weevil, Rhynchophorus ferrugineus of the second-generation fed on pieces of date palm core rinsed in sub-lethal concentrations $\left(\mathrm{LC}_{50 \mathrm{~s}}\right.$ ) of nicotinamide IGR, in addition to two crude plant extracts of Carapichea ipecacuanha and Eucalyptus camaldulensis, to show their toxicological and histopathological effects on the treated larvae. RESULTS The phytochemical studies showed two major fractions; piperine and rhodopin extracted from Carapichea ipecacuanha; gallic acid and lucenin-2extracted from Eucalyptus camaldulensis. The toxicological studies showed nearable effects and results in nicotinamide and crude extract of Carapichea ipecacuanha, while that of Eucalyptus camaldulensis was the least. The histopathological studies showed hazard malformation in the epithelial layer of the dissected treated larval midgut. CONCLUSION The present study demonstrates that both natural acetonic plant extract of Carapichea ipecacuanha and Eucalyptus camaldulensisis addition to synthetic nicotinamide IGR are capable of production of high mortality rates of Rhynchophorus ferrugineus larvae. The study further reveals that plant extracts and IGR exert effects on larval midgut histology, in this way, disrupt midgut epithelial layer of treated larvae. These disruptions may be the cause of strong larvicidal activity. Very nearable results of both nicotinamide IGR and Carapichea ipecacuanha extract may be due to presence of alkaloid fractions in both.
\end{abstract}

Key words: Rhynchophorus ferruginous, Nicotinamide, Eucalyptus camaldulensis, Carapichea ipecacuanha, toxicity, histopathology.

\section{INTRODUCTION}

The date palm, Phoenix dactylifera L., is the most important fruit crop in the Middle East. Since the mid-1980, the red palm weevil, Rhynchophorus ferrugineus (Olivier) (Col., Curculionidae), and caused serious damage to date palms in the Gulf region [1]. It was recorded for the first time in the United Arab Emirates in 1986; then was found in Saudi Arabia in 1987 and in the Islamic Republic of Iran in 1992 [2]. It was recorded in Egypt in 1992 [3 and 4],where thousands of healthy trees were damaged or lost [5].Furthermore, R. ferrugineus is a strong flyer. This increase the weevil's ability to disperse, colonize and breed at new habitats [2] and this reflects the very wide spread of the weevil through all country governorates in a relative short period and the very serious damaging on palm trees.

The conventional pesticides for insect control are costly and result in problems of residues, resistance, pollution and health hazards. Therefore, the biologist diverted their attention to insect pest management (IPM) to investigate the feasibility of new generation more safety of bio-pesticides like plant extracts and IGRs. Many investigations have been conducted on the anti-feedant effects, growth inhibition and abnormal histopathological changes in the mid gut of red palm weevil larvae. Natural insecticides as plant extracts, and natural extracts are powerful insect anti-feedant and repellents [6 and 7]. They may also disrupt the growth; inhibit the moulting and oogenesis $[8,9,10,11,12$ and 13]. The present study improved some histopathological effects of nicotinamide as IGR and different crudes extracted from Carapichea ipecacuanha and Eucalyptus camaldulensis on the mid-gut of red palm weevil larvae; the most harmful developmental stage as its feeding activity in the stem causes the destruction of the palm tree [14].

\section{MATERIALS AND METHODS}

The experimental insect:

From infested date palm trees in Sharkia Governorate large number of cocoons of red palm weevil were collected and incubated in an oblongata transparent plastic or prespex boxes $(120 * 60 * 30 \mathrm{~cm})$ with easily removable perforated covers to facilitate aeration and routine cleaning. These cocoons were kept in wet toweling until adult emergence. The newly emerged adults were fed on small pieces of red palm core till copulation, egg deposition and hatching. Larvae from sixth instar were used in this study, as it is the most active stages of feeding and easier to be dissected and observed [14]. 
Citation: Karam Hussein, Ibrahim Shoukry, Farag Ahmad Mohamed Gad, 2018. Effect Of Some Plant Extracts and Nicotinamide on Certain Histopathological Aspects In The Red Palm Weevil Larvae, Rhynchophorus Ferrugineus (Oliver) (Coleoptera: Curculionidae). Advances in Natural and Applied Sciences., 12(6): 711.

Plant crude fraction separation:

The used plants were dried, ground into fine powder, refluxed with pure acetone and stirred at $50^{\circ} \mathrm{C}$ for 30 min., the residue was extracted 3 times with acetone and the final gum of crude acetone extract was collected. TLC technique for fractionation and purification of different fractions of Carapichea ipecacuanha and Eucalyptus camaldulensis were applied and identified by different spectroscopic methods of analysis as U.V., I.R. absorption spectrum and Mass spectroscopy, the RF value for each fraction was calculated by the following equation through the guidance of Lichtenstein et al., [15].

\section{$\mathrm{RF}=\frac{\text { Distance traveled by substance }}{\text { Distance traveled by solvent }}$}

Where RF is the retention factor.

IGR and Plant extract treatments:

Effects of the nicotinamide IGR in addition to major components extracted from crude of Carapichea ipecacuanha and Eucalyptus camaldulensis on the larval midgut histopathological changes were assessed. For each extract the sub-lethal concentration $\left(\mathrm{LC}_{50}\right)$ was prepared, they were; 1794,1858 and 1893 ppms, respectively. Treated larvae of the second generation were fed on small pieces of date palm cores rinsed in the sub-lethal concentration $\left(\mathrm{LC}_{50}\right)$ of the three used extracts for one minute. All treated, and control insects were kept at $30^{\circ} \mathrm{C}, 75 \pm 5 \%$ R.H., and $12 \mathrm{D}: 12 \mathrm{~L} \mathrm{hrs.}$

\section{Histopathological studies:}

Treated and untreated larvae were dissected in Ringer's solution. The midgut was isolated and fixed in Bouin's solution then embedded in paraffin. Many sections were obtained and stained with hematoxylin and eosin according to method of Drury and Wallington [16].

Results:

Phytochemical studies:

According to table (1) and plate (I) acetonic gum extraction of Carapichea ipecacuanha was separated into two major fractions; piperine as alkaloid and rhodopin as tertiary alcohol containing compound, while that of Eucalyptus camaldulensis was separated into two major components; gallic acid and lucenin-2, first fraction is phenolic compound while the second is tannin.

Table 1: Major isolated fractions of both Carapichea ipecacuanha and Eucalyptus camaldulensis in addition to Nicotinamide.

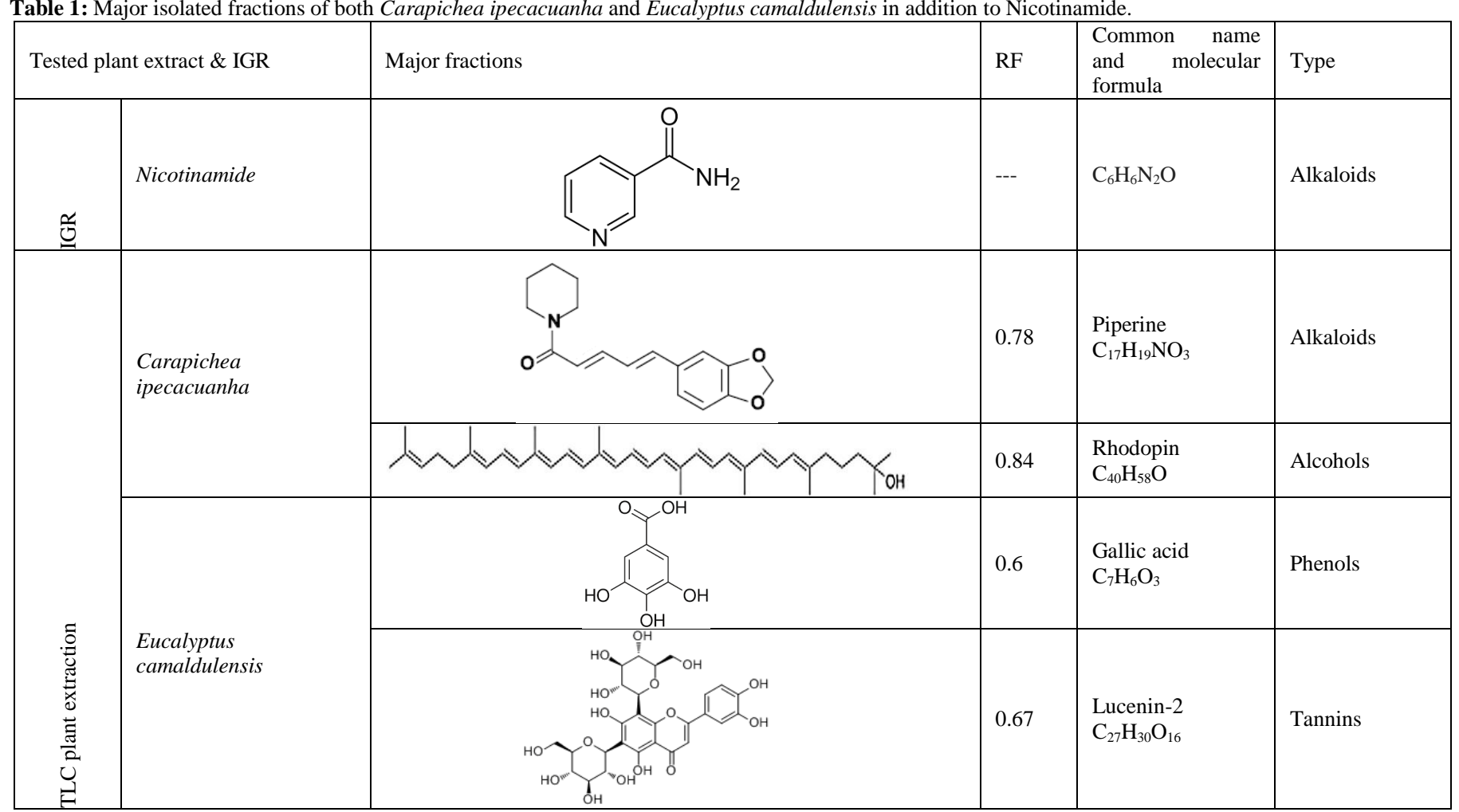

Toxicological studies:

The results present in the following Table (2) and Figure (1) showed that, the highest toxicity to the larvae was satisfied to nicotinamide ( $\mathrm{LC}_{50}$ of $\left.1794 \mathrm{ppm}\right)$ followed by Carapichea ipecacuanha extract ( $\mathrm{LC}_{50}$ of $1858 \mathrm{ppm}$ ), then by the extract of Eucalyptus camaldulensis (LC $\mathrm{LC}_{50}$ of 1893ppm), in order of descending susceptibility, respectively.

Table 2: Toxicity and the resistance ratio of the nicotinamides and crude extractions against R. ferrugineus larvae.

\begin{tabular}{|c|c|c|c|c|}
\hline \multicolumn{2}{|c|}{ Tested plant extract \& IGR } & \multirow{2}{*}{$\begin{array}{l}\begin{array}{l}\text { LC50 ppm } \\
\text { (confidence limits) }\end{array} \\
1794.517 \\
(1531.9-1951.3)\end{array}$} & \multirow{2}{*}{$\begin{array}{l}\text { Slop function } \\
6.2\end{array}$} & \multirow{2}{*}{$\begin{array}{l}\text { Resistance ratio } \\
1.000\end{array}$} \\
\hline$\underline{\underline{0}} \underline{\underline{U}}$ & Nicotinamide & & & \\
\hline \multirow{2}{*}{ 彭畩 } & Carapichea ipecacuanha & $\begin{array}{l}1858.154 \\
(1724.8-1958.6)\end{array}$ & 6.2 & 1.035 \\
\hline & Eucalyptus camaldulensis & $\begin{array}{l}1893.019 \\
(1732.9-2008.8)\end{array}$ & 5.1 & 1.055 \\
\hline
\end{tabular}

Resistance ratio compared with toxicity of nicotinamide. 
Citation: Karam Hussein, Ibrahim Shoukry, Farag Ahmad Mohamed Gad, 2018. Effect Of Some Plant Extracts and Nicotinamide on Certain Histopathological Aspects In The Red Palm Weevil Larvae, Rhynchophorus Ferrugineus (Oliver) (Coleoptera: Curculionidae). Advances in Natural and Applied Sciences., 12(6): 711.

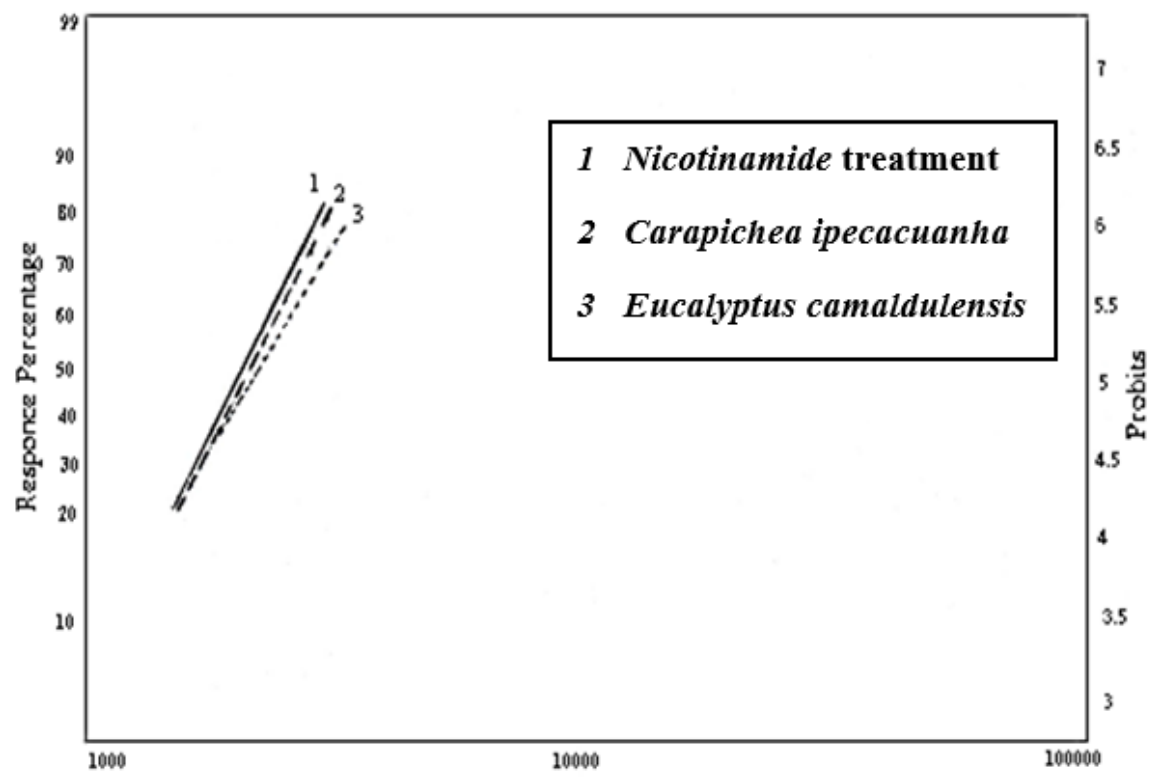

Fig. 1: Log Conc. Mortality regression lines of the nicotinamide and crude extractions against $R$. ferrugineus larvae.

\section{Histopathological studies:}

The obtained results revealed that, larval mortality due to the effect of nicotinamide was found to be more than any other used plant gum extract; however, Carapichea ipecacuanha gum extract showed a high similarity to nicotinamide effect. Therefore, alimentary canal of the larvae treated with nicotinamide was dissected in order to complete the histopathological study. The midgut of the sixth larval instar of the red palm weevil, $R$. ferrugineus contains epithelial cells and regenerative cells, the interior surface of the epithelial cells provided with borders. The epithelial cells rest on a basement membrane. The longitudinal muscle layer appears externally followed by an internal circular muscle layer. The caecal pouches or papillary crypt are thrown into folds directed to gut lumen as illustrated in Plate (II), where the muscle layer appeared detached from the gut wall [14].

The present work showed that, the nicotinamide treatment caused histological changes in the mid-gut of the old larvae of $R$. ferrugineus larvae. These changes included degeneration, vaculation, necrosis and shrinkage of the epithelial cells, movement of nuclei towards the apical part of the cell, vaculation of peritrophic membrane and detachment of muscle layers. In addition, the mid-gut of $R$. ferrugineus larvae treated with nicotinamide or Carapichea ipecacuanha gum extract showed a hazard appeared in the elongation and detachment of epithelial cells from the basement membrane. These distortions were either shredded or completely degenerated, accompanied by disappearance of cell boundaries between epithelial cells, vacuolization, and shrinkage of the epithelial cells. The transverse sections of the treated mid-gut revealed that, the nuclei moved towards the distal part of the epithelial cells and the nuclear membrane disappeared. In addition, the cytoplasm of the columnar epithelial cells appeared less condensed at the basal part of the columnar cells; degeneration of the epithelial cells of the mid-gut was clearly noted in the larvae treated with Carapichea ipecacuanha gum extract. In addition, the nuclei lose the nuclear chromatin granules and the peritrophic membrane appeared wrinkled and vacuolated. Less potent histological effects appeared when treated with Eucalyptus camaldulensis gum extract.

\section{Discussion:}

In our phytochemical studies, various active fractions were extracted from two different acetonic gum extracts of Carapichea ipecacuanha and Eucalyptus camaldulensis. Piperine and rhodopin were extracted from Carapichea ipecacuanha, this is comparable to the study of Jha et al. [17] and Yoshimatsu and Shimomura [18] who extracted several alkaloid derivatives of cephaeline and emetine. Gallic acid and lucenin-2 were isolated from Eucalyptus camaldulensis, similar results were obtained by Miranda et al. [19], Shayoub et al. [20], Pandey and Singh [21] and Ben Hassine et al. [22] all extracted gallic acid and tannin Catechin compound in different ratios from Eucalyptus camaldulensis.

The similarities between toxicological studies when using nicotinamide and crude extract of Carapichea ipecacuanha is due to the effect of nicotinamide of the used IGR and that isolated from crude extract of Carapichea ipecacuanha which act as neuro-active insecticides by inhibiting the re-oxidation of nicotinamide adenine dinucleotide (NAD) which paralyzes the insect. The extracted phenols and tannins of the Eucalyptus camaldulensis, which act as anti-feedant according to Dudt and Shure [23], showed the lowest toxicological effect. Appel and Schultz [24] showed the variation among insect species in mid-gut conditions that influenced by intrinsic physiological characteristics of the insect and by foliar oxidative enzymes, non-enzymatic oxidants, and reductants. Many insects appear to possess adaptations that relate directly to the oxidative state of the oxidative tannins and phenolics. Lower phenolic toxicity is due to detoxification by Prophenoloxidase in the insect gut, Wu et al. [25] showed that plant phenolics are of very low insect toxicity unless propheloxidase genes are lost, or the levels of phenolics exceed the catalytic activity of the gut prophenoloxidase.

Similar histopathological result was obtained by using different plant extracts against different insects as well as Abdel-Ghaffar [26] who discussed the disorders effect of Margosan-0 combined with sesame oil against the berseem hopper, Euprepocnemis plorans and Wanderley-Teixeir et al. (2006) [30] described the midgut and the pyloric valve alterations of the orthopteran, Tropidacriscollaris. Hussein et al. [28] mentioned that, the effect of plant extracts on midgut of Eariasinsulana mightbe due to digestion and absorption of plant oil. On the other hand, Ahmed [29] reported that, oil extract of chamomile plant treatment produced histopathological effects, enlargement of epithelial cells, appearance of vacuoles at the apical part of the cell and destruction of the peritrophic membrane of Culexpipiens larvae. Nasiruddin and Mordue [30] studied the histological and ultrastructure changes caused by azadirachtin on the midgut of locust. Their findings revealed necrosis of epithelial cells, enlargement of cytoplasmic inclusions and small sized striated borders, while Rembold et al. [31] confirmed that, Azadirachtina good factors for tissue specific in corporation in malpighian tubules of Locustamigratoria. On the other hand, Abo El-Ghar et al. [32] proved histological effects of abmectin on mid-gut of Spodopteralittoralis, which had similar hazard shredding and erosion on the lining epithelium. For the same insect Abdullah [33] showed destroyed epithelial cells, vaculation of cytoplasm and dissolving of nuclei of epithelial cells in the mid-gut of 10 days old larvae when treated with Boxuschinensis oil and precocene II.

In conclusion, the strong larvicidal activity of the used plant extracts and nicotinamide IGR may be due to their hazard histopathological effects on larval midgut. Treatment with these plant extracts and IGR greatly disturbed midgut histology of the larvae; the most harmful stage of the red palm weevil, causing various deterioration effects. 
Citation: Karam Hussein, Ibrahim Shoukry, Farag Ahmad Mohamed Gad, 2018. Effect Of Some Plant Extracts and Nicotinamide on Certain Histopathological Aspects In The Red Palm Weevil Larvae, Rhynchophorus Ferrugineus (Oliver) (Coleoptera: Curculionidae). Advances in Natural and Applied Sciences., 12(6): 7 11.

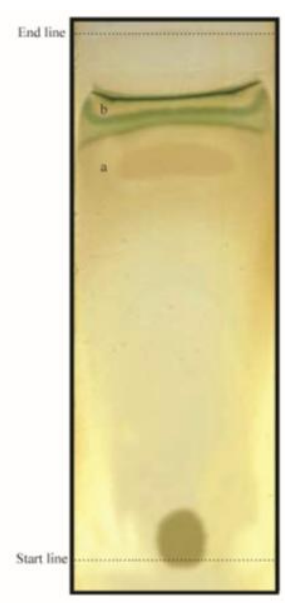

(A)

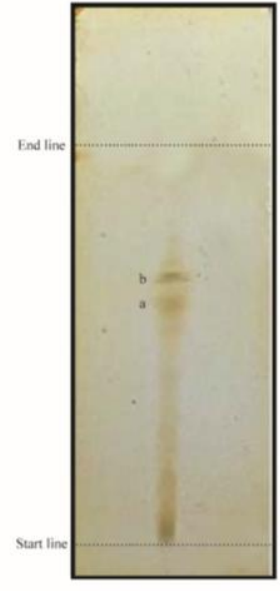

(B)

Plate (I) TLC of isolated plant extract from both

(A) acetonic extract of Carapichea ipecacuanha (a- Piperine and b- Rhodopin) in developing system (Chloroform : Petroleum ether $2: 1$ ).

(B) acetonic extract of Eucalyptus camaldulensis (a- Lucenin-2 and b- Gallic acid respectively) in developing system (Diethyl ether: Petroleum ether $1: 2.5$ ).
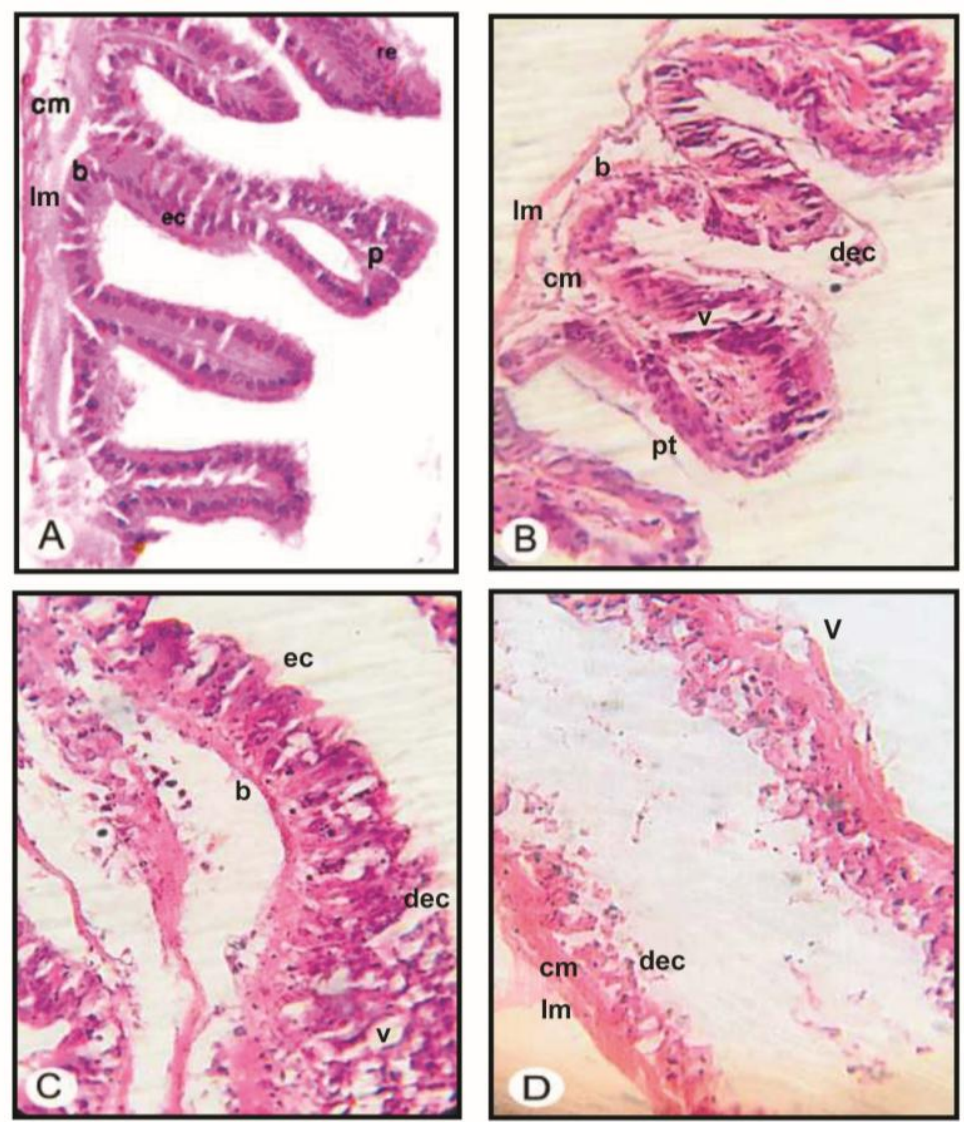

Plate (11); Photomicrographs of T.S. of the mid-gut of untreated and treated RPW larvae
(A) Untreated,
(B) Treated with nicotinamide,
(C) Treated with Carapichea gum extract,
(D) Treated with Eucalyptus gum extract.

b: basement membrane

cm: circular muscle

ec: epithelial cells

dec: destroyed epithelial cells

f: food material

l: lumen

Im: longitudinal muscle

p: papillary crypt

pt: peritrophic membrane

re: regenerative cells

v: vacuoles 
Citation: Karam Hussein, Ibrahim Shoukry, Farag Ahmad Mohamed Gad, 2018. Effect Of Some Plant Extracts and Nicotinamide on Certain Histopathological Aspects In The Red Palm Weevil Larvae, Rhynchophorus Ferrugineus (Oliver) (Coleoptera: Curculionidae). Advances in Natural and Applied Sciences., 12(6): 711.

\section{REFERENCES}

[1] Abraham, V.A., M.A. Al Shuaibi, J.R. Faleiro, R.A. Abuzuhairah and RS.EV. Vidyasagar, 1998. An integrated management approach for red palm weevil, Rhynchophorus ferrugineus Oliv., a key pest of date palm in the Middle East. Sultan Qabus Univ. J. Sci. Res., Agric. Sci., 3: 77-84.

[2] Murphy, S.T. and B.R. Briscoe, 1999. The red palm weevil as an alien invasive: biology and the prospects for biological control as a component of IPM. Biocontrol News lnf., 20: 35-46.

[3] Saleh, M.R.A., 1992. Red palm weevil, Rhyncophorus ferrugineus Oliver is first record in Egypt and introduced in African continent. List No. 10634 Africa: Collection No. 22563. Int. Institute of Entomol., London.

[4] Cox, M.L., 1993. Red palm weevil, Rhynchophorus.ferrugineus, in Egypt. FAO Plant Prot. Bull., 41: 30-31.

[5] EL-Sebaey, Y., 2004. Field evaluation of certain insecticides against red palm weevil Rhynchophorus ferrugineus Oliv. (Coleoptera, Curculionidae) in Egypt. Egypt. J. Agric. Res., 82(4): 1591-1599.

[6] Butterworth, J.H. and E.D. Morgane, 1968. Isolation of a substance that suppresses feeding in locusts. Chem. Comm., 8: 23-24.

[7] Zanno, P.R., E. Miura, K. Naknishi and D.L. Elder, 1975. Structure of the insect phagorepllent azadirachtin. J. Amer. Chem. Soc., 97: 1975-1977.

[8] Garcia, E.D.S. and H. Rembold, 1984. Effect of azadirachtin on ecdysis of Rhodniusprolixus. J. Insect. Physiol., 30: 939-941.

[9] Dorn, A., J.M. Rademacher and E. Sehn, 1986. Effects of azadirachtin on the moulting cycle, endocrine system, and ovaries in last instar larvae of the milk weed bug Oncopeltusfasciatus. J. Insect. Physiol., 32: 231-238.

[10] Koul, O., K. Amanai and T. Ohtaki, 1987. Effects of azadirachtin on the endocrine events of Bombyxmori. J. Insect Physiol., $33: 103-108$.

[11] Steets, R., 1976. The effect of a purified extract of the fruits of Azadirachta Indica On Leptinotarsa Decemlineata. Z. Angew. Entomol., 82: 169-176.

[12] Rembold, H. and K.P. Sieber, 1981. Inhibition of oogenesis and ovarian ecdysteroid synthesis by azadirachtin in Locusta migratoria migratorioides. Z. Naturf., 36: 466-469.

[13] Senthilnathan, S. and K. Sehoon, 2005. Effects of Melia azedavachL. extract on the teak defoliator Hyblaeapuera (Lepidoptera: hyblaeidae). Crop Prot.,10: $1-5$.

[14] Harris, M.N., J.J. Norzainih and O.N. Wahida, 2015. Morphology and Histology of the Digestive System of the Red Palm Weevil Larva, Rhynchophorus ferrugineus, Oliver (Coleoptera: Dryophthoridae). $3^{\text {rd }}$ CAMS-2015, Singapore: 32-37.

[15] Litchtenstein, E.P., K.R. Linoge, K.R. Schulz, H.K. Schnoes and G.T. Carter, 1974. Insecticidal and synergistic components isolated from dill plants. J. Agric. Food Chem., 22(4): 658-664.

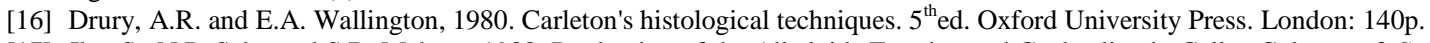

[17] Jha, S., N.P. Sahu and S.B. Mahato, 1988. Production of the Alkaloids Emetine and Cephaeline in Callus Cultures of Cephaelis ipecacuanha. Planta medica 1988: 483-584.

[18] Yoshimatsu, K. and K. Shimomura, 1991. Emetic alkaloid formation in root culture of Cephaelis ipecacuanha. Phytochemistry, (30)-2: 505-507.

[19] Miranda, I., L. Lima, T. Quilho, S. Knapic and H. Periera, 2016. The bark of Eucalyptus sideroxylon as a source of phenolic extracts with anti-oxidant properties. Industrial crop and products, (82): 81-87.

[20] Shayoub, M.E., A.D.H. Dawoud, M.A.M. Abdelmageed, A.M. Ehassan and A.M. Ehassan, 2015. Phytochemical analysis of leaves exract of Eucalyptus camaldulensisDehnh. Omdurman J. of Pharmaceutical Science., 2(1): 64-71.

[21] Pandey, B. and S. Singh, 2014. Evaluation of antimicrobial potential of Eucalyptus camaldulensis L. J. of Pharmaceutical, Chemical and Biological Science., 2(3): 166-171.

[22] BenHassine, D., M. Abderrabba, Y. Yvon, A. Lebrihi, F. Mathieu, F. Couderc and J. Boujaila, 2012. Chemical composition and in Vitro evaluation of the antioxidant and antimicrobial activities of Eucalyptus gillii essential oil extracts. Molecules, (17): 9540-9558.

[23] Dudt, J.F. and D.J. Shude, 1994. The Influence of Light and Nutrients on Foliar Phenolics and Insect Herbivory. Ecology, 75(1): 86-98.

[24] Appel, H.M. and J.C. Schultz, 2017. Activity of Phenolics in Insects: The role of Oxidation. BLSC, 59: 609-620.

[25] Wu, K., J. Zhang. Q. Zhang, S. Zho, Q. Shao, K.D. Clark, Y. Liu and E. Ling, 2015. Plant phenolics are detoxified by propheloxidase in the insect gut. Scients Reports, 5: 1-15.

[26] Abdel-Ghaffar, A.A., 2004. Phagodetervency induced by Margosan-0 as combined with sesam oil against the berseem hopper Euprepocnemis plorans (charp) (Orthoptera: Acrididae). J. Egypt. Ger. Soc. Zool., (43E): 69-86.

[27] Wanderley-Teixeir, V., C.A. Teixeria, M.F. Cunha, M.C.K. Costa, L.S.F. Veiga and V.J. Oliveira, 2006. Histological description of the midgut and the pyloric value of Tropidacriscollaris stoll. (Orthoptera: Romaleidae). Braz. J. Biol., 66: 1045-1049.

[28] Hussein, M.A., S.E. Hafez, L.S. El-Sherif and M.A. Hewady, 1994. Histopathological effects of chamomile against larvae of spiny bollworm, Eariasinsulana(F.) (Noctuidae: Lepidoptera). J. Fac. Educ., 19: 178-200.

[29] Ahmed, F.A., 1995. Safety and efficiency of natural and synthetic insecticides used in the control of culicine mosquitoes in Egypt. Ph.D. Thesis, Fac. Sci., Zagazig Univ., Egypt.

[30] Nasiruddin, M. and A.J. Mordue, 1993. The effect of azadirachtin on the midgut histology of the locust, Schistocercagregariaand Locust migratoria. Tissue and cells. Proc. Pakistan Congr. Zool., 25(6): 875-884.

[31] Rembold, H., T. Muller and B. Subrahmanyan, 1988. Tissue specific incorporation of Azadirachtin in the malpighiantubuels of Locustamigratoriazeit. Fur. Natur. Bio., 43(11-12): 903-907.

[32] Abo El-Ghar, G., H. Radwan, Z. El-Bermawy and Zidan, 1994. Histological effects of abmectin on the mid-gut of Spodopteralittoralis(Lepidoptera, Noctuidae) larvae. Bull. Entomol. Soc. Egypt. Econ. Ser., 21: 41-45.

[33] Abdullah, M.A.R., 2009. Toxicological and histopathological studies of Boxuschinensisoil and precocene II on larvae of the red palm weevil, Rhynchophorus ferrugineus (Oliver) (Coleoptera :Curculionidae ). Egypt. Acad. J. biol. Sci., 2(2): 45-54. 